\title{
Analysis of the Requirement for the Ships Using Methanol as Fuel
}

\author{
Michael Rachow ${ }^{1}$, Steffen Loest ${ }^{2}$, Agus Dwy Bramastha ${ }^{3}$
}

\begin{abstract}
It is one of promised solution for being shipping fuel because of it feedstock and produces less pollution than fossil fuel. Methanol is one of new fuel in the shipping industry; because of that there are lack of regulation for this fuel. IMO has not release regulation of using methanol as fuel but there is some draft is in process. The document that can be found to represent the draft of IMO IGF Code is report of SubCommittee of Carriage Cargo and Containers (CCC) 3-3. Classification society that has the regulation for using methanol is LR and DNV GL. Comparing the three regulations and selecting the regulation that has high safety level is the best way to design the methanol-fueled ship. The result shows that there still some different opinion on the three regulations that regulate the methanol as ship fuel. Some regulation also doesn't mention about the detail material that should be use in the system. Calculation method to selecting pipes thickness also different. To make it safe, the thick one should be used. Implementation the regulation on board ship resulting loses the payload of their cargo. The specific fuel consumption will be increased by factor $46 \%$ compared to fuel oil SFOC and the storage tank shall be protected by cofferdam that takes a lot of space. To safe ships space the service tank is recommended put in the main deck to prevent the use of protective cofferdam.
\end{abstract}

Keywords—design, emmision, fuel, regulation, requirement, system.

\section{INTRODUCTION}

$\mathrm{C}$ limate change and environment problem are the most discussed issue for the future shipping industry. One major environmental problem is air pollution. Although air pollution from ships does not have the direct cause and effect associated with, for example, an oil spill incident, it causes a cumulative effect that contributes to the overall air quality problems encountered by populations in many areas, and also affects the natural environment, such as tough acid rain [1]. The main international shipping convention regulating emissions to air from ships is the IMO International Convention on the Prevention of Pollution from Ships (referred to as MARPOL) Annex VI. MARPOL Annex VI, first adopted in 1997, limits the main air pollutants contained in ships exhaust gas, including sulfur oxides (SOx) and nitrous oxides (NOx), and prohibits deliberate emissions of ozone-depleting substances (ODS). Under the revised MARPOL Annex VI, the global Sulphur cap will be reduced from current $3.50 \%$ to $0.50 \%$, effective from 1 January 2020, subject to a feasibility review to be completed no later than 2018 [1]. The new IMO Tier III regulation which takes effect on 1st January 2016 in North American and US Caribbean ECAs for a ship with the keel laying in 1st January 2016. Because of that, the new ships with keel laying after that date and sail in North American and US Caribbean ECAs must follow this regulation. The IMO tier III regulates the NOx emissions must be reduced by

Michael Rachow, Hochschule Wismar University, Germany. Email: michael.rachow@hs-wismar.de

Steffen Loest, Hochschule Wismar University, Germany. Email: steffen.loest@hs-wismar.de

Agus Dwy Bramastha, Department of Maritime Engineering Hochschule Wismar University, Germany. E-mail: adbramastha @ gmail.com approximately $75 \%$. One of the solutions to archive this regulation is using cleaner fuel such as Methanol.

Methanol is a safe, cost-effective alternative marine fuel. With the growing demand for cleaner marine fuel, methanol is a promising alternative fuel for ships that help the shipping industry meet increasingly strict emissions regulations [2]. It is one of promised solution for being shipping fuel because of it feedstock and produces less pollution than fossil fuel. It significantly reduces emissions of sulfur oxides (SOx), nitrogen oxides (NOx) and particulate matter. It is one of the top five chemical commodities shipped around the world each year. Unlike some alternative fuels, it is readily available through existing global terminal infrastructure. Currently, methanol produced using natural gas as raw materials, but It can be produced from an enormous raw material such as coal, biomass and the most interesting from $\mathrm{CO}_{2}$. IF future technology can make methanol from $\mathrm{CO}_{2}$ more effective, it will make the world more sustainable because $\mathrm{CO}_{2}$ is one of the major cause of global warming.

The objective of this research is to applicated the methanol for diesel engine fuel. Currently, IMO has not release regulation of using methanol as fuel but there is some draft is in process. Classification society that has the regulation for using methanol is LR and DNV GL. Because there is no basic international regulation to design, compared both regulations is needed before designing the ship fuel system.

\section{METHOD}

\section{II.1 Methanol as Ship Fuel}

Use of fuel in marine is large. It estimated that international shipping consumes around 300 million tons of HFO annually. The North Sea/Baltic Sea SECA area accounts for 20 to 25 million tons of annual HFO consumption. These figures highlight the potential market for low sulfur fuels such as methanol. There are 
some researchers about using methanol as fuel. Ellis and Tanneberger [3] do "Study on the use of ethyl and methyl alcohol as alternative fuels in shipping in Europe" They research for availability, environmental consideration, regulation, and safety assessment for fuel system on the passenger and cargo ship. The availability of methanol is widely available because it is used extensively in the chemical industry like shows in figure 1. Total global production capacity in 2013 was just over 100 million tons.

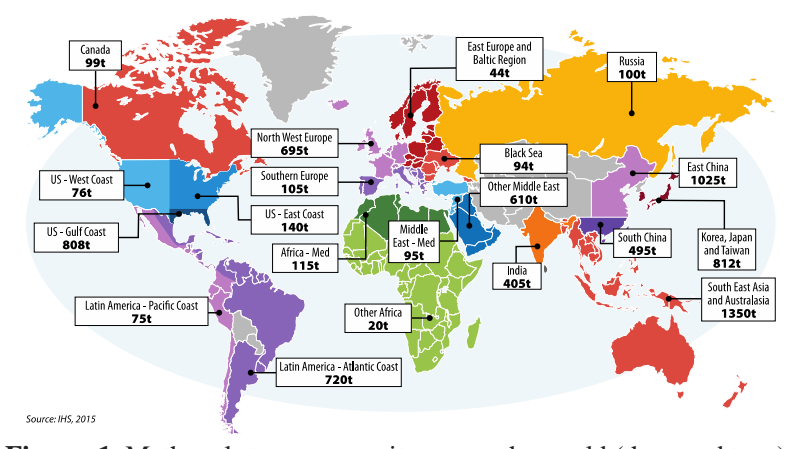

Figure. 1. Methanol storage capacity across the world (thousand tons)

In Europe, there are large bulk storage terminals in both Rotterdam and Antwerp, and it is transported both with short sea shipping and by inland waterways to customers. Methanol has many advantages regarding environmental impact as compared to conventional fuels - they are clean burning, contain no sulfur, and can be produced from renewable feedstock. They do the safety assessment in fuel system by using HAZID method on passenger and cargo ship.

Brynolft et al [4] do study about "Environmental assessment of marine fuels: liquefied natural gas, liquefied biogas, methanol, and bio-methanol". They compare the life cycle environmental performance of methane, the energy carrier in LNG, and methanol as marine fuels, considering both natural gas and biomass as raw material by using Life cycle assessment (LCA). The results of this research explain that methanol produced from natural gas would significantly improve the overall environmental performance. However, the impact on climate change is of the same order of magnitude as with the use of heavy fuel oil. For methanol produced from has the potential to reduce the impact of climate change. In other hands, Perez Fortez et al [5] do research about "Methanol synthesis using captured $\mathrm{CO} 2$ as raw material: Techno-economic and environmental assessment". In this paper, they explain that if using $\mathrm{CO} 2$ as raw material there is 0.239 $\mathrm{MtCO} 2 / \mathrm{yr}$ not produced compared to conventional $\mathrm{MeOH}$ plant. If this plan has effective enough to produce methanol, it will be competitive enough to be environmental friendly fuel.

\section{II.2 Fuel Consumption Calculation}

Fuel oil consumption is one of important indicator on ship because it indicates the emission from the ship. To calculate fuel oil consumption in tons is using equation 1. Because MAN S26MC6 is not methanol fueled engine and has to be convert first to use methanol as fuel, for SFOC calculation is based on MAN Project Guide for methanol engine, especially MAN S40ME-B9.

$W=P_{M C R} \times S F O C \times t \times 10^{-6}$

TABLE 1.

LOWER CALORIFIC VALUES OF FUELS

\begin{tabular}{lc}
\multicolumn{2}{c}{ Fuel Type } \\
\hline LCV, $\mathbf{k J} / \mathbf{k g}$ \\
\hline Diesel & 42,700 \\
Methane (GI) & 50,000 \\
Ethane (GIE) & 47,500 \\
Methanol (LGIM) & 19,900 \\
LPG (LGIP) & 46,000 \\
\hline
\end{tabular}

When the engine converted from using HFO or MDO to methanol as fuel there will be some changing in fuel consumption. In the table 1 explain that Diesel has higher LCV than methanol. It causes some changing in
SFC of the engine. In the table 2 explain increasing $1 \%$ of standard LCV $(42,700)$ will be reduce the SFOC by factor $1 \%$ [6].

TABLE 2 .

SPECIFIC FUEL OIL CONSUMPTION CONVERSION FACTOR

\begin{tabular}{llc}
\hline \multicolumn{1}{c}{ Parameter } & \multicolumn{1}{c}{ Condition Change } & SFOC Change \\
\hline Scav, air coolant temperature & Per 10 C rise & $+0.41 \%$ \\
Blower inlet temperature & Per 10 C rise & $+71 \%$ \\
Blower inlet pressure & Per 10 mbar rise & $-0.05 \%$ \\
Fuel, lower calorific value & Per 1\% & $-1.00 \%$ \\
\hline
\end{tabular}




\section{II.3 Fuel Transfer System}

Fuel transfer system is the system that transfers fuel from tank to other tank or consumer. The main component in this system are pump, pipe and pipe accessories. To choose the pump, there are two main factor should be considered. First is capacity of the pump and second is the head of the pump.

$Q=\frac{V}{t}\left[\frac{m^{\mathrm{a}}}{h}\right]$

Equation 2 shows the formula to calculate the capacity of the pump or $\mathrm{Q}\left[\mathrm{m}^{3} / \mathrm{h}\right]$. Where $\mathrm{V}\left[\mathrm{m}^{3}\right]$ is the volume of fuel that would be transfer and $\mathrm{t}[\mathrm{h}]$ is the required time to transfer the fuel. To calculate head pump, First thing need to know is the pipe specification such as the diameter and materials of the pipe. Minimum internal diameter of the pipe is calculated by equation 3 .

$$
\begin{aligned}
& Q\left[\frac{m^{s}}{s}\right]=A\left[m^{2}\right] \times v\left[\frac{m}{s}\right] \\
& Q\left[\frac{m^{s}}{s}\right]=0.25 \pi d^{2}\left[m^{2}\right] \times v\left[\frac{m}{s}\right] \\
& d=\sqrt{\frac{Q}{0.25 \pi v}}[\mathrm{~m}]
\end{aligned}
$$

After get the minimum diameter of the pipe, the minimum thickness of the pipe should be calculated. The equation to get the minimum pipe thickness is depending on the regulation or classification society rules. CCC 3-3 using calculation based to get the minimum pipe thickness. Equation 4 is the formula for pipe thickness based on CCC 3-3 Regulation. The detail formula can be seeing in the CCC 3-3 Section 7.3 Requirement for general pipe design.

$t[\mathrm{~mm}]=\frac{\left(t_{0}+b+c\right)}{1-\left(\frac{a}{100}\right)}$

Lloyd Register using calculation to know minimum pipe thickness but there is minimum requirement for it based on the minimum internal diameter of the pipe. Lloyd Register explain the minimum pipe thickness in Rules and Regulation for the Classification of Ship Part 5 Chapter 12 Section 10 for Austenitic and Duplex stainless steel.

$t[\mathrm{~mm}]=\left(\frac{P d}{20 \sigma e+P}+c\right) \frac{100}{100-a}$

Equation 5 shows the minimum pipe thickness equation from Lloyd Register. The result must be compared to the table in in Rules and Regulation for the Classification of Ship Part 5 Chapter 12 Section 10 Table 12.10.1. If the result less than requirement in the table, the thickness requirement will follow the table requirement. DNV GL Regulation doesn't have equation to calculate the

\section{RESULTS AND DISCUSSION}

\section{A. IMO Requirement and Classification Rules}

\section{A.1. Ship Design and Arrangement}

DNV GL and CCC 3-3 draft have detail explain about portable fuel tank and have same opinion on it. Otherwise LR provision rules haven't explain about portable fuel tank LR and DNV GL have same opinion minimum pipe thickness. They only use table requirement. They explain the minimum pipe thickness in DNV GL RU Ship Part 4 System and Component Chapter 6 Piping system Section 9. After gets the inside diameter and minimum thickness of the pipe, the next step is to selecting the pipe based on the standard such as JIS, ANSI, DIN or ISO.

Once the pipe specification have been selected, now head pump can be calculated. Head pump consist of 4 variables. First is head static. Head static pump is calculated from pump inlet till the end of discharge. Second is head pressure, which is the different pressure between outlet and inlet of the pump. Third is Head Velocity. It is difference velocity of fluid between in suction line in suction and discharge of pump. The last is head loss. There are two type of head loss there are minor loses and mayor loses. Mayor loses is loses come from the friction of liquid to the pipe. To calculate the major head loss, Rn number is used to know the characteristic of the flow. Equation 6 is the formula for Rn number.

$R n=\frac{v\left[\frac{m}{g}\right] \times d H[m]}{u\left[\frac{m^{2}}{s}\right]}$

From $\mathrm{Rn}$ find the value of $\mathrm{f}$ (friction factor) by using moody diagram or moody friction factor calculation and find the head loss. Equation 7 shows the formula to calculate mayor head loss.

$h_{f}=\frac{f \times L[m] \times v^{2}\left[\frac{m}{g}\right]^{2}}{d H[m] \times 2 g\left[\frac{m}{g^{2}}\right]}$

Minor loses is loss from installation of pipe accessories such as valve, elbow strainer, etc. Each of these accessories has loses factor the symbol is k. For calculate the minor loses, the formula is explain in equation 8 .

$h_{m}=\frac{k \times v^{2}\left[\frac{m}{g}\right]^{2}}{2 g\left[\frac{m}{g^{2}}\right]}$

Mayor and minor loses have to be calculated both in suction side and the discharge side. After, those four variables have been defined; the next step is to sum the head static, head pressure, head velocity and the head loss.

about minimum distance between fuel tanks and ship side that is $800 \mathrm{~mm}$, but in the CCC 2-3 in paragraph 15 said there need further discussion in distance between fuel tanks and ship side, the reason was the minimum distance may need to be different to that required for LNG fuel tanks. Because of that in the CCC 3-3 there is no explanation about minimum distance for fuel tank. 


\section{A.2. Fuel Contaiment System}

In DNV GL and LR Rules, they mention about minimum 2 number of fuel tanks installed on board ship, Otherwise in $\mathrm{CCC} 3-3$ there is no explanation about minimum number of tank. CCC 3-3, LR and DNV GL agree to make the protective cofferdam for fuel containment system

\section{A.3. Inert Gas System}

In the inert gas system there are a different opinion about vertical efflux velocity between DNV GL and CCC 3-3, In the DNV GL recommendation is at least $20 \mathrm{~m} / \mathrm{s}$ but CCC recommendation is $30 \mathrm{~m} / \mathrm{s}$. In the LR Provision Rules there is no explanation about it. CCC 33 explain about detail configuration for inert gas supply line. Inert gas supply line shall be fitted with two shutoff valves in series with venting valve in between. In additional non-return valve shall be installed between the block and bleed arrangement.

\section{A.4. Material and General Pipe Design}

CCC 3-3 explains about the general pipe design such as the minimum wall thickness but there is no explanation about the type material that should be use for methanol. Same as DNV GL there is no detail material that should be use for using methanol as fuel. The detail type material is explained in LR Provision rules. They don't recommend using material that sensitive to methanol such as aluminums alloys, galvanized steel, lead alloys, Nitrile, Butyl and not using austenitic stainless steel if the methanol containing water. They recommended using duplex type stainless steel or austenitic manganese steel.

For minimum wall thickness calculation they have different method. In CCC only using calculation to determine the minimum wall thickness. LR also using calculation but there is a minimum wall thickness for each material based on pipe diameter. For DNV GL only using table for the minimum wall thickness.

\section{A.5. Fuel Supply to Consumer}

In the fuel supply to consumer section both CCC, LR and DNV GL are agree to use double walled pipe when passing enclosed spaces. The double walled pipe is not required in cofferdams surrounding fuel tanks, fuel pump room/fuel preparation room, or other space considered as hazardous. In the fuel pump room or in the CCC the called fuel preparation room there is a different between DNV GL and CCC. CCC recommended that the air change is at least 15 air change per hour if there are no leakage in fuel penetration room ad increase to 30 air change per hour if there is any leakage. DNV GL only explain the minimum air change is 30 air change per hour.

A.6. Fire Safety

In this section there are several different between CCC, LR and DNV GL. For the structural fire protection, in CCC there is minimum size of cofferdam that is $900[\mathrm{~mm}]$ in the fire integrity tank of fuel tank cofferdam boundaries facing high risk space but there is no explanation about it in LR or DNV GL. ARAFFF system is explain in CCC and LR. In CCC the system shall be install in fuel tank that located in open deck, bunker station. In LR the installation of ARAFFF shall be install in deck for the coverage and positioning shall be addressed in the risk-based studies. DNV GL doesn't mention about ARAFF installation. For fire extinguishing of engine room and pump room CCC and DNV GL only said the fire extinguisher medium shall be suitable for the extinguishing of methyl alcohol fires. Otherwise LR mention the fire extinguisher shall comply with MSC/Circ.1165. They don't mention specifically about what type of fire extinguisher shall be use in machinery room and pump room.

A.7. Ventilation

For the ventilation system CCC, LR and DNV GL has same opinion about the system. They agree that the minimum air change is 30 air change per hour in the hazardous area.

\section{A.8. Control Monitoring and Safety System}

CCC3-3, LR and DNV GL have same opinion about control monitoring and safety system for methanol fueled ship. Beside in LR and DNV GL, they have detail explanation in form of table compared to CCC3-3 only the general explanation.

\section{B. Design Requirement}

As the result of the comparison between three types of regulation that are CCC3-3, LR and DNV GL, there are some different between three of those rules. In this section there will be discussion, which regulation will be taken to design the ship in the study case and the reason.

\section{B.1 Ship Design and Arrangement}

Fuel tank and ship side distance minimum is $800 \mathrm{~mm}$. In the CCC 3-3 there is no explanation of the minimum distance between fuel tank and ship side. In the previous CCC 2-3, the regulation is being remove because they think there should be different minimum distance between methanol and LNG fuel because methanol has liquid form. Current MethaShip and 7 methanol ship project they both follow the $800 \mathrm{~mm}$ minimum distance. From the safety aspect if there is any collusion, there will be some second barrier but have to remind the void space must have the gas inert system.

B.2 Fuel Contaiment System

Minimum 2 fuel tanks have to be onboard ship. CCC 3-3 doesn't explain about the minimum fuel tanks. Otherwise in the SOLAS Regulation II-1/26.11 and classification society for fuel tank there are minimum 2 fuels tanks.

\section{B.3 Inert Gas System}

Vertical efflux velocity $30 \mathrm{~m} / \mathrm{s}$. AMS Glossary said efflux velocity is the average flow rate of material emitted into atmosphere. Compared to $20 \mathrm{~m} / \mathrm{s}$ efflux velocity, $30 \mathrm{~m} / \mathrm{s}$ has more safety benefit to prevent methanol concentration in certain room.

B.4 Material and General Pipe Design

Material that recommended to use is Duplex type stainless steel or austenitic manganese steel. Duplex type stainless steel or austenitic steel are more reliable to methanol corrosive compare to other metal.

\section{B.5 Fuel Supply to Consumer}

For air change in fuel prearation room 30 air change per hour. In CCC they explain that if there is no leakage the minimum air change is 15 air change per hour and if there is leakage the air change is improve to 30 air change per hour. Because methanol is low flash point fuel and if there is any leakage will be very dangerous. 
For safety aspect it better to take the highest air change. For structural fire protection its better to use $900 \mathrm{~mm}$ cofferdam.

\section{B.6 Fire Safety}

For structural fire protection its better to use $900 \mathrm{~mm}$ cofferdam between engine room and fuel preparation room.

\section{Study Case}

In this section, author makes study case to design fuel system of 4000 DWT Tanker. Table 3, and 4 shows the ship, main engine. This data is needed to design ship fuel system. The ship has not existed and still in design process.

TABLE 3.

SHIPS GENERAL DATA

\begin{tabular}{|c|c|c|}
\hline Name of Ship & Doris Tanker & Units \\
\hline Type & Oil Chemical Tanker & \\
\hline Lwl & 102.96 & $\mathrm{~m}$ \\
\hline Lpp & 99 & $\mathrm{~m}$ \\
\hline Breadth (B) & 15.8 & $\mathrm{~m}$ \\
\hline Height $(\mathrm{H})$ & 8.4 & $\mathrm{~m}$ \\
\hline Draught $(\mathrm{T})$ & 6.336 & $\mathrm{~m}$ \\
\hline Coefficient Block $(\mathrm{Cb})$ & 0.62 & \\
\hline Vs & 13.5 & knot \\
\hline Voyage Endurance & 5 & days \\
\hline GT & 3352 & \\
\hline DWT & 4000 & DWT \\
\hline Payload & 3880.7 & ton \\
\hline
\end{tabular}

TABLE 4.

MAIN ENGINE SPECIFICATION

\begin{tabular}{lcl}
\hline \multicolumn{1}{c}{ Specification } & Detail & Units \\
\hline Type & MAN B\&W 7S26MC6 & \\
Power & 2800 & $\mathrm{~kW}$ \\
Speed & 250 & $\mathrm{rpm}$ \\
SFOC & 179 & $\mathrm{~g} / \mathrm{kWh}$ \\
SFOC $_{\text {MeOH }}$ & 260.9 & $\mathrm{~g} / \mathrm{kWh}$ \\
SFOC $_{\text {MGO }}$ & 8.95 & $\mathrm{~g} / \mathrm{kWh}$ \\
Quantity & 1 & \\
\hline
\end{tabular}

Based on MAN LGI system overview shows in Figure 2 , there will be 5 main point of component that should be found. The first is the capacity of the storage tank, second the transfer system from storage to service tank, third is transfer system from methanol service tank to fuel valve train, fourth is find the fuel valve train specification and the last is transfer system from fuel valve train to main engine.

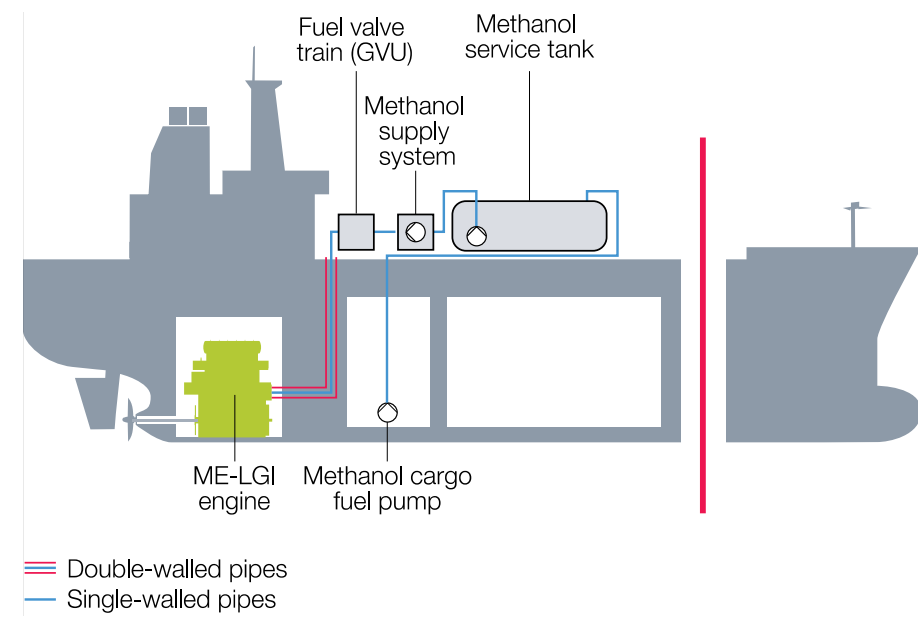

Figure. 2. ME-LGI System overview [7]

C.1. Main Engine Fuel System

Ship is planned have endurance for 5 days (120 hours). The ship needs minimum $126 \mathrm{~m} 3$ of methanol and 3.5 $\mathrm{m}^{3}$ of MGO for pilot fuel. For ship service tank size, the tank shall be supply minimum 8 hours to main engine.

TABEL 5.

FUEL TANK REQUIREMENT AND TANK DESIGN CAPACITY

\begin{tabular}{|c|c|c|}
\hline Type & Requirement for 5 days $\left[\mathrm{m}^{3}\right]$ & Design $\left[\mathrm{m}^{3}\right]$ \\
\hline MeOH Storage Tank & 126.9 & 131.86 \\
\hline MeOH Service Tank & 8.8 & $10 \times 2$ \\
\hline MGO Pilot Tank & 3.5 & $7.97 \times 2$ \\
\hline
\end{tabular}


Methanol storage tank will be placed in between engine room and slop tank from frame 28 until frame 33 . The distance between storage tank shipside and fuel preparation room is $800 \mathrm{~mm}$. This distance is used as a second barrier if there is any leakage in the tank.
Methanol service tank will be placed in ship's main deck. This location gives advantage in the ventilation side. The tank that will be use is Lapesa LF 10P and in the table 6 shows the detail specification.

TABLE 6.

METHANOL SERVICE TANK DIMENSION

\begin{tabular}{lcl}
\hline \multicolumn{1}{c}{ Series } & Lapesa LF 10 P & Units \\
\hline Net Volume & 10 & $\mathrm{~m}^{3}$ \\
Nominal Diameter & 1750 & $\mathrm{~mm}$ \\
L1 & 3400 & $\mathrm{~mm}$ \\
$\mathrm{H}$ & 100 & $\mathrm{~mm}$ \\
$\mathrm{~B}$ & 1200 & $\mathrm{~mm}$ \\
\hline
\end{tabular}

For MGO Pilot Fuel Tank will be located Inside Engine room. It joins with MGO Service Tank for Generator and has capacity of $7.97 \mathrm{~m}^{3}$.

To design methanol fuel system, there will be 2 pump that should be find. The first is methanol transfer pump and methanol supply pump. The specification of the pump chose based on the capacity and minimum head of the pump. For the methanol transfer pump the minimum capacity is $4.38 \mathrm{~m} 3 / \mathrm{h}$ this based on the minimum capacity of methanol service tank and the assumption of minimum time to fill the tank that is 2 hours. From the capacity of the pump, will get the minimum internal diameter for the pipe. Head of pump is fined by calculation loss in pipe system suction and discharge side of the pump.

Selecting pipe for the fuel system is based on two factors that are materials of the pipe and the thickness of the pipe. The material of the pipe will be used duplex stainless steel type (EN.1.4462-UNS S31803, S32205 $2205)$ with the mechanical properties explained in the table 15 .

TABLE 7.

MECHANICAL PROPERTIES OF DUPLEX STAINLESS STEEL ACC. TO EN 10272

\begin{tabular}{llll}
\hline \multicolumn{1}{c}{ Tensile strength $\mathbf{R m}$} & $\mathbf{6 5 0} \mathbf{- 8 8 0}$ & $\mathrm{N} / \mathbf{m m} \mathbf{2}$ \\
\hline Proof strength Rp0,2 & $\min 450$ & & $\mathrm{~N} / \mathrm{mm} 2$ \\
Proof strength Rp1,0 & $\min 340$ & & $\mathrm{~N} / \mathrm{mm} 2$ \\
Hardness & $\max 270$ & $\mathrm{HB}$ & \\
\hline
\end{tabular}

TABLE 8 .

SUMMARY OF FUEL SYSTEM PUMP.

\begin{tabular}{lcccc}
\hline \multicolumn{1}{c}{ Type } & \multicolumn{3}{c}{ Calculation } & Design \\
\cline { 2 - 5 } & $\mathrm{Q}[\mathrm{m} 3 / \mathrm{h}]$ & $\mathrm{H}[\mathrm{m}]$ & 5 & $\mathrm{H}[\mathrm{m}] \mathrm{h}]$ \\
Transfer Pump & 4.83 & 9.11 & 1.6 & 10 \\
Supply Pump & 1.18 & 63.16 & 5.9 & 60 \\
Circulation Pump & 4.05 & 46.81 & 0.04 & 50 \\
Pilot Supply Pump & 0.04 & 60 & 0.7 & 60 \\
Pilot Circ. Pump & 0.14 & 40 & 50 \\
\hline
\end{tabular}

TABLE 9.

SUMMARY OF FUEL SYSTEM PIPE THICKNESS BASED ON CCC 3-3, LR, DNV GL

\begin{tabular}{lcccc}
\hline \multirow{2}{*}{ Type } & $\mathbf{C C C ~ 3 - 3}$ & LR & DNV GL & Design \\
\cline { 2 - 5 } & {$[\mathrm{mm}]$} & {$[\mathrm{mm}]$} & {$[\mathrm{mm}]$} & {$[\mathrm{mm}]$} \\
Transfer Pipe & 1.11 & 1.60 & 1.60 & 2.00 \\
Supply Pipe & 1.10 & 1.60 & 1.60 & 2.00 \\
Circulation Pipe & 1.09 & 1.60 & 1.60 & 1.60 \\
\hline
\end{tabular}

TABLE 10.

DETAIL PIPE SPECIFICATION FOR METHANOL FUEL SYSTEM USED IN STUDY CASE SHIP.

\begin{tabular}{lccccc}
\hline \multicolumn{1}{c}{ Specification } & Transfer Pipe & Supply Pipe & Circulation Pipe & $\begin{array}{c}\text { Pilot Supply } \\
\text { Pipe }\end{array}$ & $\begin{array}{c}\text { Pilot Circ. } \\
\text { Pipe }\end{array}$ \\
\hline Materials & Duplex Stainless & Duplex Stainless & Duplex Stainless Steel & Carbon Steel & Carbon Steel \\
& Steel & Steel & & & - \\
Diameter Nominal & DN 40 & DN 25 & DN 20 & - & - \\
Inside Diameter & $40.50 \mathrm{~mm}$ & $26.00 \mathrm{~mm}$ & $21.80 \mathrm{~mm}$ & $4.00 \mathrm{~mm}$ & $6.00 \mathrm{~mm}$ \\
Outside Diameter & $44.50 \mathrm{~mm}$ & $30.00 \mathrm{~mm}$ & $25.00 \mathrm{~mm}$ & $8.00 \mathrm{~mm}$ & $10.00 \mathrm{~mm}$ \\
Schedule Number & DIN/ISO Series 1 & DIN/ISO Series 1 & DIN/ISO Series 1 & DIN/ISO & DIN/ISO \\
& & & & Series 1 & Series 1 \\
Thickness & $2.00 \mathrm{~mm}$ & $2.00 \mathrm{~mm}$ & $1.60 \mathrm{~mm}$ & $2 \mathrm{~mm}$ & $2 \mathrm{~mm}$ \\
\hline
\end{tabular}

\section{C.2. Engineering Technical Solution}

Methanol concentration in the room is recommended not more than $200 \mathrm{ppm}$. To reduce the risk of the pipe is divided to the section-using valve. If there is any leakage the valve will between the pipes will be closed. This makes the amount of methanol content that been release can be controlled.

Fuel preparation room located from frame 28 to frame 35. There is $900 \mathrm{~mm}$ separation between fuel preparation room and engine room. This cofferdam is used based on 
regulation to reduce the risk of fire. Between methanol storage tank and the room, there is $800 \mathrm{~mm}$ double barrier for the tank. In this coffined space will be support by venting system. The room has length of $4.7 \mathrm{~m}$; width 4.5 $\mathrm{m}$; and the high is $7.2 \mathrm{~m}$. The total volume of the room is $152.28 \mathrm{~m}^{3}$. The fuel preparation room is recommended to have maximum 200ppm of methanol content. This makes the maximum volume of methanol can be released if there is any leakage is $\mathbf{0 . 0 3 0 5} \mathrm{m}^{3}$ of methanol.

The fuel transfer pipe has the diameter of $40.5 \mathrm{~mm}$. The pipe has been divided by flange into three sections. The first section is from the tank to fuel preparation room that has the length of $0.8 \mathrm{~m}$. Second, is from preparation room wall to pump. This section has the length of $0.68 \mathrm{~m}$. The last and the longest is from the pump to fuel service tank which has the length of $8.4 \mathrm{~m}$. The minimum distance between valves is getting by dividing the maximum leakage volume by the surface area of the pipes. The results, the minimum distance between valves is $23.65 \mathrm{~m}$. Compared to the longest pipe in the transfer system that is $8.4 \mathrm{~m}$, this transfer pipe is in the low-risk condition, even without installing any additional valves.

C.3. Fuel System P\&ID

In the P\&ID System there will be some component number to easily check the specification, quantity and location. List codes are according to the designer. Based on Main Engine Project Guide, Author makes the equation for coding the equipment, such as:

$$
\text { XX-AA-BB or XX-AAA-BBB }
$$

Where:

XX or XXX : System Code

AA or AAA : Component Code

BB or BBB : Component Number

For design Methanol Fuel System, the system code is FS and continued by component code. In the table 11 shows the list of component for the fuel system. The table also explain the require quantity and specification of each component.

TABLE 11.

P\&ID COMPONENT LIST FOR FUEL SYSTEM

\begin{tabular}{|c|c|c|c|c|c|}
\hline No & Symbol & Code & Name & Specification & Qty. \\
\hline 1 & & FS-BV-01-08 & Butterfly Valve & DN40, PN6, Duplex Stainless Steel & 8 \\
\hline 2 & & FS-NRV-01-04 & Screw Down Non Return Valve & DN40, PN6, Duplex Stainless Steel & 4 \\
\hline 3 & & FS-NRV-05-08 & Screw Down Non Return Valve & DN25, PN6, Duplex Stainless Steel & 4 \\
\hline 4 & & FS-NRV-09-12 & Screw Down Non Return Valve & DN20, PN6, Duplex Stainless Steel & 4 \\
\hline 5 & & FS-SV-01-02 & Safety Valve & 1 bar, Duplex Stainless Steel & 2 \\
\hline 6 & & FS-SV-03-04 & Safety Valve & 6 bar, Duplex Stainless Steel & 2 \\
\hline 7 & & FS-SV-05-06 & Safety Valve & 10bar, Duplex Stainless Steel & 2 \\
\hline 8 & & FS-CVR & Remotely Operated Closing Valve & Duplex Stainless Steel & 5 \\
\hline 9 & & FS-TBV & Three Way Globe Valve & DN20,PN6, Duplex Stainless Steel & 2 \\
\hline 10 & & FS-ST & Simplex Filter & Finished Product & 2 \\
\hline 11 & & FS-DS & Discharge Side & Finished Product & 9 \\
\hline 12 & & FS-BS & Bell mount Suction & Finished Product & 5 \\
\hline 13 & & FS-PI & Pressure Indicator & Finished Product & 15 \\
\hline 14 & & FS-TI & Temperature Indicator & Finished Product & 5 \\
\hline 15 & & FS-LAH & High Level Alarm & Finished Product & 5 \\
\hline 16 & & FS-LAL & Low Level Alarm & Finished Product & 5 \\
\hline 17 & & FS-APF & Air Pipe with Flame Screen & Finished Product & 4 \\
\hline 18 & & FS-SN & Sounding Pipe & Finished Product & 4 \\
\hline 19 & & FS-TP-01-02 & Methanol Transfer Pump & Sili Pump-05-CWF-10 & 2 \\
\hline 20 & & FS-SP-01-02 & Methanol Supply Pump & Sili Pump-YCB-16/06 & 2 \\
\hline 21 & & FS-CP-01-02 & Methanol Circulation Pump & Sili Pump-CYB-40-200 & 2 \\
\hline 22 & $\perp$ & FS-BUC & Bunker Connection & Finished Product & 4 \\
\hline
\end{tabular}

Fuel System P\&ID explain about the process flow and the component of the system. In figure 3 shows P\&ID of methanol fuel system in the study case ship. As explained before, there are 5 main point of component that should be found to complete the methanol fuel system. In the figure there are number start from 1 to 5 that representing the component.

Number 1 explains the methanol storage tank. It is located in the fuel preparation room start from frame 28 until 35 at starboard and portside. It shall be protected by $800 \mathrm{~mm}$ cofferdam. It equipped with 3 sensors, there are 
LAH (High Level Alarm), LAL (Low Level Alarm), TI (Temperature Indicator). Sounding pipe and Air pipe with flame screen are installed in the tank. Sounding pipe to measure the depth of liquid and Air pipe to maintain pressure on the tank.

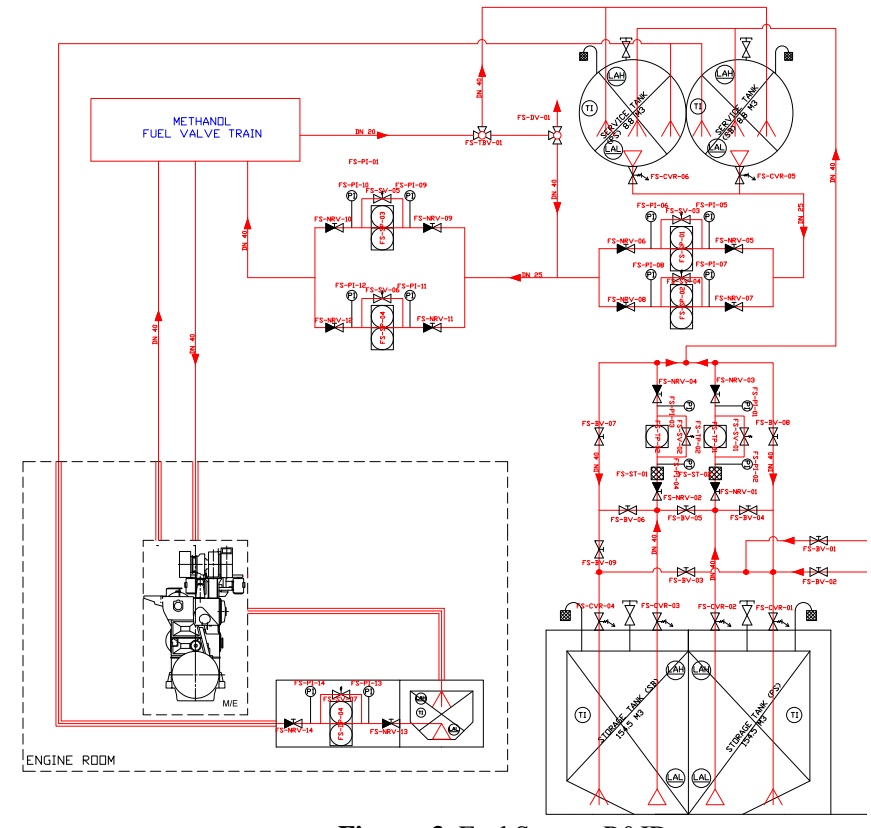

Figure. 3. Fuel System P\&ID

Number 2 is fuel transfer system from storage tank to service tank. This system shall have 2 pumps to comply with regulation and for the safety reason if one of the pump doesn't work. The pump that used in the system is centrifugal type pump, which has capacity of $5 \mathrm{~m} 3$ and $10 \mathrm{~m}$ of head. Because of the limited access to the methanol pump specification, in this study case author using regular pump specification.

Number 3 is methanol service tank. It is located in the main deck. It manufactured by Lapesa and build from duplex stainless steel to prevent the methanol corrosion. Same as methanol storage tank, service tank also equipped with 3 sensors, there are LAH (High Level Alarm), LAL (Low Level Alarm), TI (Temperature Indicator). Sounding pipe and Air pipe with flame screen are installed in the tank.

Number 4 is called methanol supply system. The system consist of two main components, there are supply pump and circulation pump. The specifications of the pump usually explain in the Project Guide of the Main Engine. Because the main engine hasn't yet existed, Author make approaching by find out the ration of the fuel injection to the engine, circulation pump, and supply pump. The result, supply pump has capacity of $1.6 \mathrm{~m}^{3}$ and circulation pump has capacity of $5.9 \mathrm{~m}^{3}$. The head pressure of the pump is same as fuel oil system. Where the supply pump has 6 bar and circulation pump 4 bar of head. Because the pumps are put in series, the final head will be $10 \mathrm{bar}$, it is same as the FVT nominal working pressure.

The last is number 5, which is transfer fuel from FVT to Maine Engine. The only manufacture for methanol fuel valve train is electrofueltech. FVT function is to delivery and to prevent any failure when the system in emergency condition. For pipe specification transfer fuel from FVT to Main Engine same as the circulation pipeline, except when the pipe enter engine room. In this part, pipe shall be used is double walled type. Double walled pipe that used in study case ship is manufactured by UWIRA, which has inner pipe diameter of $25 \mathrm{~mm}$ and the outer pipe diameter of $38 \mathrm{~mm}$. If there is any overflow of fuel the fuel will be back to FVT. From FVT the fuel can be transferred to service tank or back to the circulation pump to be transfer again to Main Engine.

\section{C.4. Fuel System Component Layout}

Fuel system component layout is plotting the component that has been selected in the methanol fuel system to the location inside the ship. There are 3 main locations for the component. First is in the main deck. In this deck there are several of methanol component such as methanol service tank, methanol fuel supply system and fuel valve train as shows in figure 4. Methanol service tank located in the main deck to make it well ventilated. This makes the tank do not need extra double barrier. 


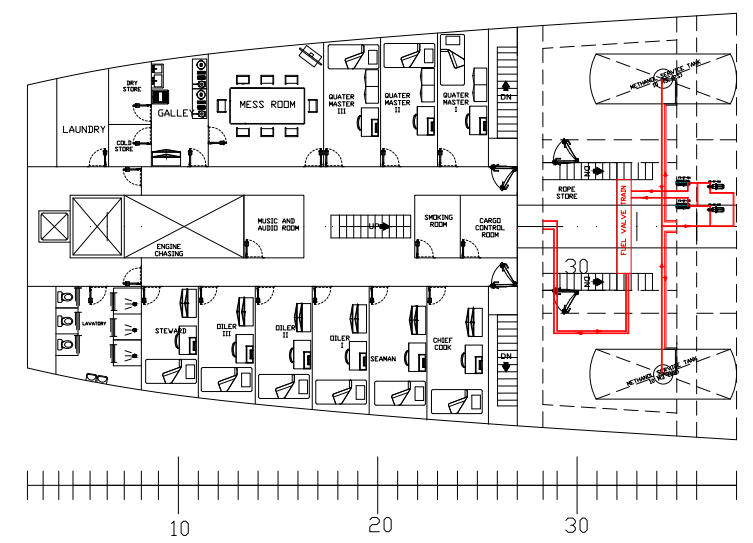

Figure. 4. Methanol Fuel System on Main Deck

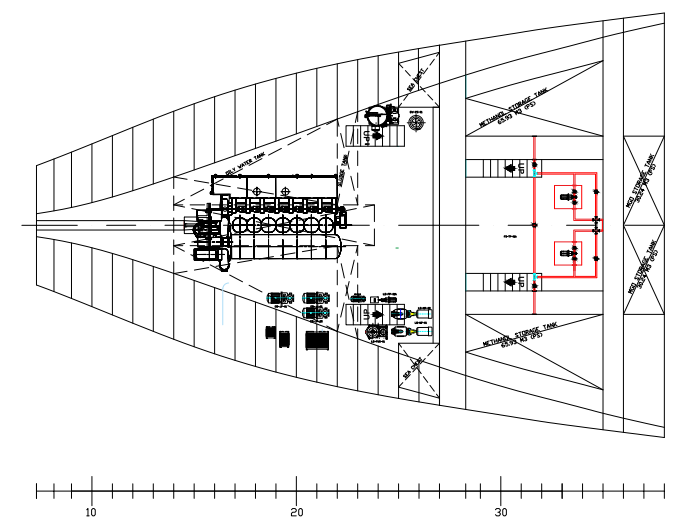

Figure. 5. Methanol Fuel System on Double Bottom

Second is on the double bottom where the location of the methanol fuel transfer pump and methanol storage tank as shows in Figure 5. Because located inside ships hull, the tank should be protected by double barrier. Based on the regulation, the distance between shipside to the tank and tank to fuel preparation room is $800 \mathrm{~mm}$, from storage tank to engine room is $900 \mathrm{~mm}$. Beside the storage tank, there are also two-fuel transfer pump. These ventilation systems needed to prevent increasing of methanol vapor concentration inside the room if there is any leakage on the pump system. The recommendation for methanol vapor concentration room is below 200 ppm. Based on the methanol pipe mitiagation calculation the maximum pipe and valves length is $21.48 \mathrm{~m}$. As shows in Figure 6, the average distance between pipes and valves is $4 \mathrm{~m}$. For access to fuel preparation room there are two stairs in the room from main deck.

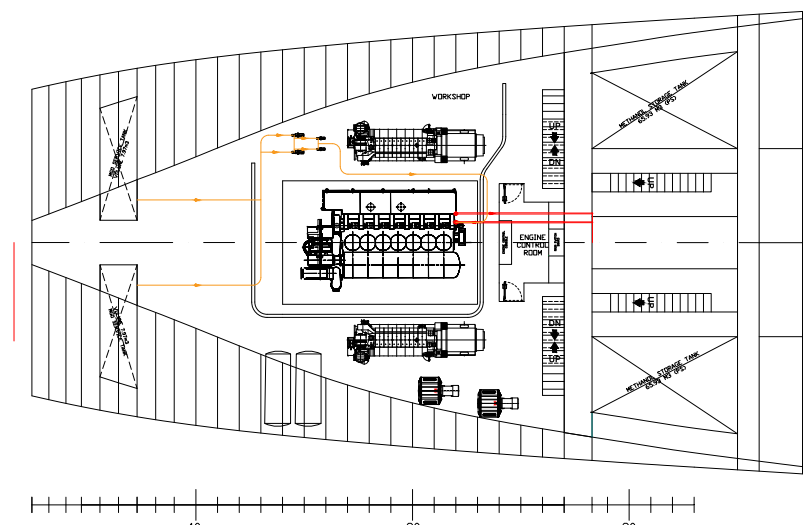

Figure. 6. Methanol Fuel System on Platform 

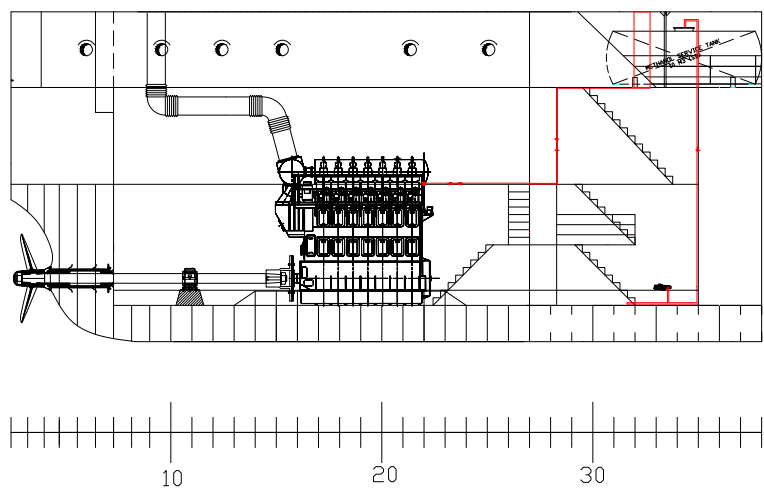

Figure. 7. Side View of Methanol Fuel System

The last is the fuel injection location. It located near the platform deck as shows in Figure 6. In this also where the overflow fuel comes out. The yellow line is representing the MGO fuel. It use as pilot fuel in the system. Figure 7 shows the side view of the ship to get exact location of the component.The ship also has cofferdam to separate the fuel preparation room from

\section{CONCLUSION}

Based on the result of this research, can be drawn the following conclusion;

1. There all still some different opinion on the three regulations that regulate the methanol as ship fuel. In ship and design arrangement section, DNV GL and LR explain about $800 \mathrm{~mm}$ minimum distance between tank and ship side but there is no explanation in CCC 3-3. For fuel containment system DNV GL and LR explain about minimum 2 fuel tank have to be onboard ship, but CCC 3-3 doesn't explain it. In the inert gas system, there are the different opinion about vertical efflux velocity between DNV GL and CCC 3-3, In the DNV GL recommendation is at least $20 \mathrm{~m} / \mathrm{s}$ but CCC recommendation is $30 \mathrm{~m} / \mathrm{s}$. In the LR Provision Rules, there is no explanation about it. For the material of the pipe only LR explain it in detail and recommended using duplex type or austenitic manganese steel otherwise DNV GL and CCC 3-3 doesn't explain it in detail. For general pipe design CCC 3-3, LR and DNV GL have the different method. For fire safety, there are several differences between CCC, LR and DNV GL. For the structural fire protection, in CCC there is the minimum size of cofferdam that is 900 [mm] in the fire integrity tank of fuel tank cofferdam boundaries facing high-risk space but there is no explanation about it in LR or DNV GL.

2. To full fill the IMO and classification society requirement, the regulation that will be used to design is the regulation, which can provide the high level of safety. The fuel tank and shipside distance minimum $800 \mathrm{~mm}$ will be taken. Onboard, the ship will be minimum 2 fuel tanks. For the material of the pipe will be used duplex type stainless steel and for minimum pipe wall thickness, will choose the engine room. The distance is $900 \mathrm{~mm}$ and it's complied with CCC 3-3 Regulation.. The cofferdam should be well ventilated Surrounding the tank by cofferdam is one of solution to prevent failure when there is a leakage. The fuel transfer pump located in fuel preparation room shall be in enclosed space. It make easier to monitories when there is any leakage in the pump.

thick one. In the structural fire, safety aspect will be using $900 \mathrm{~mm}$ barrier between fuel preparation room and engine room.

3. Implementation of the regulation on board ship is quite challenging. The ship will lose the payload of their cargo. The specific fuel consumption will be increased by factor $46 \%$ compared to fuel oil SFOC and the storage tank shall be protected by cofferdam that takes a lot of space. To prevent the protected cofferdam, the service tank is recommended put in the main deck. Where in the main deck the tank in well-ventilated condition. For pilot fuel, it's recommended to join it with MGO service tank for the generator, because of the small consumption. For the safety aspect when there is any leakage in the transfer pipe is good. Because the last and the longest is from the pump to fuel service tank which has a length of $8.4 \mathrm{~m}$. The minimum distance between valves is getting by dividing the maximum leakage volume by the surface area of the pipes. The results, the minimum distance between valves is $23.65 \mathrm{~m}$. Compared to the longest pipe in the transfer system that is $8.4 \mathrm{~m}$, this transfer pipe is in the low-risk condition, even without installing any additional valves.

\section{REFERENCES}

[1] “Air Pollution." [Online]. Available: http://www.imo.org/en/Our Work/environment/pollutionprevention/airpollution/pages/airpollution.aspx. [Accessed: 01-Oct-2017].

[2] "Methanol as a Marine Fuel| Methanex Corporation." [Online]. Available: https://www.methanex.com/about-methanol/methanolmarine-fuel. [Accessed: 01-Oct-2017].

[3] J. Ellis and K. Tanneberger, "Study on the use of ethyl and methyl alcohol as alternative fuels in shipping," Eur. Marit. Saf. Agency, 2015.

[4] S. Brynolf, E. Fridell, and K. Andersson, "Environmental assessment of marine fuels: liquefied natural gas, liquefied biogas, 
International Journal of Marine Engineering Innovation and Research, Vol. 3(2), Dec. 2018. 58-68 (pISSN: 2541-5972, eISSN: 2548-1479)

methanol and bio-methanol," J. Clean. Prod., vol. 74, pp. 86-95, Jul. 2014.

[5] M. Pérez-Fortes, J. C. Schöneberger, A. Boulamanti, and E. Tzimas, "Methanol synthesis using captured CO 2 as raw material: Techno-economic and environmental assessment," Appl. Energy, vol. 161, pp. 718-732, Jan. 2016.

[6] D. \& T. MAN, "MAN B\&W S40ME-B9.5-TII Project Guide." 2017.

[7] MAN, "Using Methanol Fuel in the MAN B\&W ME-LGI Series." 2015. 